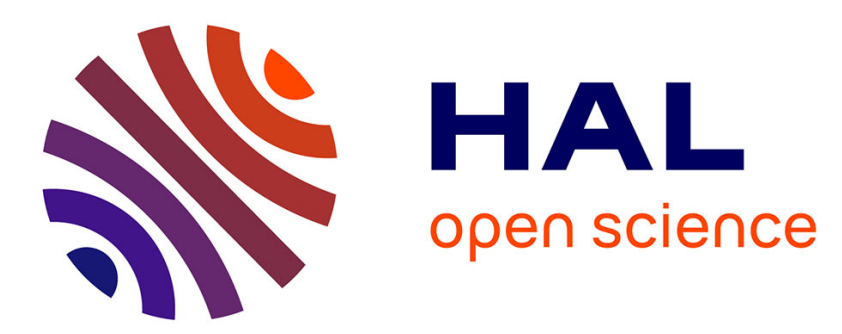

\title{
A clockwise rotation of Southern Apulia?
}

\author{
M. Tozzi, C. Kissel, R. Funiciello, C. Laj, M. Parotto
}

\section{To cite this version:}

M. Tozzi, C. Kissel, R. Funiciello, C. Laj, M. Parotto. A clockwise rotation of Southern Apulia?.

Geophysical Research Letters, 1988, 15 (7), pp.681-684. 10.1029/GL015i007p00681 . hal-03551351

\section{HAL Id: hal-03551351 \\ https://hal.science/hal-03551351}

Submitted on 1 Feb 2022

HAL is a multi-disciplinary open access archive for the deposit and dissemination of scientific research documents, whether they are published or not. The documents may come from teaching and research institutions in France or abroad, or from public or private research centers.
L'archive ouverte pluridisciplinaire HAL, est destinée au dépôt et à la diffusion de documents scientifiques de niveau recherche, publiés ou non, émanant des établissements d'enseignement et de recherche français ou étrangers, des laboratoires publics ou privés. 


\title{
A CLOCKWISE ROTATION OF SOUTHERN APULIA ?
}

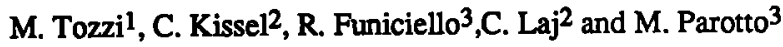

Abstract: New paleomagnetic results from 13 sites sampled in Eo-Oligocene autochthonous formations in the extreme South of the Apulian platform in southeastem Italy are presented.They suggest that this region has undergone a clockwise rotation of about $25^{\circ}$ since the Eo-Oligocene. This rotation is opposite in sense to that obtained from the Cretaceous formations in the Gargano, which has generally been assumed to affect the entire foreland. These new data suggest that the Tertiary structural evolution of this region may be distinct from that of central peninsular Italy and related to that of northwestern Greece on the other side of the Southern Adriatic Sea.

\section{Introduction}

In the last 10 or 15 years a large number of paleomagnetic studies have contributed to a better understanding of the geodynamical evolution of the Mediterranean, by associating some areas with the European or with the African plates, or by providing evidence of a separate evolution. Reviews of the available data have been given by Lowrie [1980] and by Vandenberg and Zijderveld [1982]. More recently, Lowrie [1986] has discussed the results from Sicily, peninsular Italy, Istria and the Southem Alps, the movements of which have also certainly played a key role in the geodynamical evolution of the Central Mediterranean. The Mesozoic and Early Tertiary paleomagnetic directions from many sites of this "Adriatic promontory" show an overall consistency: while north of the Alps all the studies yield (European) northeastern to northern declinations, over the entire promontory northwestern declinations have been generally observed, and the position of the calculated virtual geomagnetic poles are near the Apparent Polar Wander Paths (APWP) for Africa [Van der Voo and French, 1974; Tauxe et al., 1983]. However, significant departures from the African APWP of VGPs from individual regions are evidence of a considerable tectonic deformation. For instance, Lowrie [1986] has concluded that the Tertiary movement of the central part of Italy (counterclockwise rotation of about $17^{\circ}$ of autochthonous Gargano and about $25^{\circ}$ of allochthonous Umbria) is significantly larger than those of Sicily [Besse et al., 1984] or of the Southerm Alps [Vandenberg and Wonders, 1976].

Clearly there is reasonable evidence that the movement of the Italian Peninsula cannot be described as that of a rigid block, and that the different regions have, to some degree, evolved independently. In this letter we report preliminary paleomagnetic data from Tertiary autochthonous formations in the extreme South of Apulia, which indicate a clockwise rotation of this region since about the middle Tertiary, with respect to either Africa or Europe. This rotation is, in the opposite sense to that of the Cretaceous formations in Gargano, but is similar to the one observed in Northwestern Greece, on the other side of the Adriatic Sea.

\footnotetext{
${ }^{1}$ Dottorato di Ricerca, Dipartimento di Scienze della Terra, Università di Roma, Italy.

${ }^{2}$ Centre des Faibles Radiactivités, Laboratoire Mixte CNRS-CEA, Gif-sur-Yvette, France.

${ }^{3}$ Dipartimento di Scienze della Terra, Università di Roma, Italy.
}

Copyright 1988 by the American Geophysical Union.

Paper number $8 \mathrm{~L} 6783$.

0094-8276/88/008L-6783\$03.00

\section{Geological setting and sampling}

The Apulian foreland is the largest autochthonous massif in the Central Mediterranean. The main geologic characteristics of its southernmost part, the Salento, and the location of the sampling sites are shown schematically on Figure1.

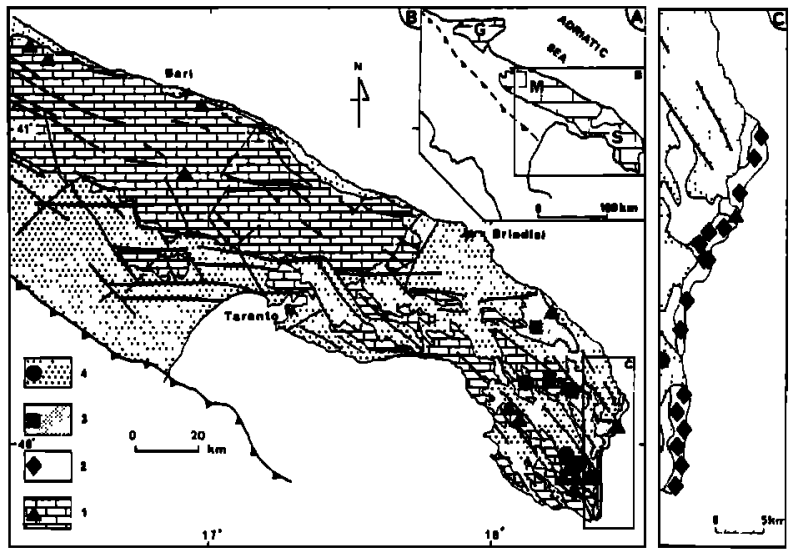

Fig.1. A: Schematic map of Southeastern Italy showing the location of the Apulian foreland (G: Gargano; M: Murge; S: Salento) with respect to the front of the Apennine thrust. B: main geologic units, structural setting and location of the sampled paleomagnetic sites. 1: Cretaceous carbonate platform; 2: Eo-Oligocene limestones (Calcari di Castro); 3: Miocene formations (Pietra Leccese); 4: Plio-Pleistocene formations including Calcareniti del Salento. C: enlarged view of the Calcari di Castro formation showing the location of the sites sampled in it.

From a stratigraphic point of view, this region is characterized by a thick Mesozoic carbonate platform, consisting of over 6000 meters of reef, back reef and dolomitic limestones, which conformably overlie an only gently deformed Paleozoic basement. A series of well stratified (150 $\mathrm{m}$ thick) limestones with rich microfauna, known as 'Calcari di Castro' were deposited during the Eocene and Oligocene. Although this formation is mostly of a rather coarse material, very fine grained levels can be found interbedded with the coral-algal strata. During the Miocene large amounts of calcarenites, limestones and yellow sands, the 'Pietra Leccese' formation, was also deposited over most of the region. Finally during the Pliocene and the Early Pleistocene coarse grained calcarenites and organogenic sands, known as 'Calcareniti del Salento' were deposited during marine transgressive events.

From a tectonic point of view, the main feature of the Salento is the Cretaceous carbonatic-dolomitic ridge which coincides, to a first approximation, with old Mesozoic reef zones. These reefs lie at the core of a large antiform structure which, on an outcrop scale, is complicated by small, slightly arcuate folds and by some asymmetric folds. The transitional facies of the Calcari di Castro crops out only in the eastern areas. Brittle deformation studies have led to the recognition of at least two distinct tectonic phases and also of the reactivation of old fault planes, so that this region appears to have a structural setting more complex than usually encountered in foreland areas.

A total of 380 cores from 36 sites were sampled in Cretaceous formations (12 sites), in the Calcari di Castro (16 sites), in the Pietra Leccese (4 sites), and in the Calcareniti del Salento (4 sites). Freshness of the outcrops, clear bedding attitude indications and fine grained material were the main criteria for selecting the sites in the Calcari di Castro. An attempt to select outcrops on the basis of their Natural Remanent Magnetization 
(NRM) measured with a portable spinner magnetometer failed because all the sites had an NRM lower than the noise level of the instrument $\left(3 \times 10^{-4} \mathrm{~A} / \mathrm{m}\right)$.

\section{Paleomagnetic data}

All measurements were done using a LETI 3-axis cryogenic magnetometer. The magnetic mineralogy has been carefully investigated. Alternating field (AF) demagnetization of Anhysteretic Remanent Magnetization, Isothermal Remanent Magnetization (IRM) acquisition in fields up to $1.6 \mathrm{~T}$ followed by AF and thermal demagnetization of the saturated IRM were studied. No difference whatsoever was observed in the magnetic mineralogy of normal and reverse samples and all the measurements indicate that magnetite is the main magnetic carrier both in normal and reversed samples (Figure 2).

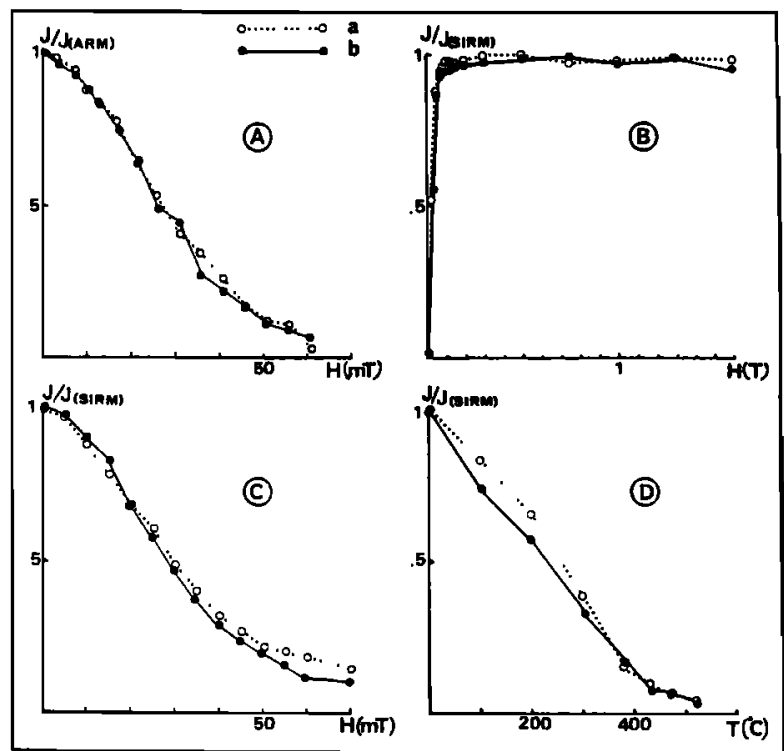

Fig.2. Typical diagrams showing that the magnetic mineralogy of the reversed (a) and normal (b) samples is identical and dominated by fine-grained magnetite. A: Alternating field (AF) demagnetization of Anhysteretic Remanent Magnetization; B acquisition of Isothermal Remanent Magnetization (IRM); $C$ and $\mathrm{D}: \mathrm{AF}$ and thermal demagnetization of the Saturated IRM.

The NRM intensities of the sampled formations range from about $1 \times 10^{-5} \mathrm{~A} / \mathrm{m}$ for the Cretaceous limestones to about $5 \times 10^{-4} \mathrm{~A} / \mathrm{m}$ for the calcarenites while the Calcari di Castro average about $1 \times 10^{-4}$ to $1 \times 10^{-3} \mathrm{~A} / \mathrm{m}$. Stepwise thermal demagnetization from room temperature to the limit of reproducible results was used throughout.

Consistent results were obtained from 13 of the sites sampled in the Eo-Oligocene Calcari di Castro (Table 1), all characterized by good quality demagnetization diagrams, some of which are shown in Figure 3. Unambiguous paleomagnetic directions were obtained between 200 and $450^{\circ} \mathrm{C}$, after removal of a small, low temperature, secondary component. The directions obtained from the Calcari di Castro before bedding correction are aligned along the N-S axes with a mean inclination about $10^{\circ}$ lower than that of the present-day. Because the bedding plane attitude is similar for all the sampled sites, no fold test could be performed. Although the grouping of the data is not as good after bedding correction (but not significantly by an F-test), we have a strongly positive reversal test. Indeed, when both reversed and norma samples are present in the same site, they are distributed over different stratigraphic levels and their paleomagnetic directions are perfectly antipodal (Figure 4). This rules out the possibility of widespread remagnetization due to a possible tectonic event In addition, the different analyses described above have shown that both reversed and normal samples have an identical magnetic mineralogy, dominated by magnetite. We can thus reject the hypothesis of a selective and progressive weathering which
Table I: Paleomagnetic data from Apulia

\begin{tabular}{|c|c|c|c|c|c|c|c|}
\hline \multirow{2}{*}{ Sites } & \multirow{2}{*}{$\mathbf{n}$} & \multicolumn{2}{|c|}{ before B.C } & \multicolumn{2}{|c|}{ after B.C } & \multirow{2}{*}{$\mathbf{K}$} & \multirow{2}{*}{$\alpha_{95}$} \\
\hline & & D & I & D & I & & \\
\hline $\begin{array}{l}\text { Cretaceo } \\
\text { PU 05 } \\
\text { PU 11 } \\
\text { PU } 33\end{array}$ & $\begin{array}{l}\text { us } \\
6 \\
4 \\
6\end{array}$ & $\begin{array}{r}147.6 \\
35.8 \\
355.0\end{array}$ & $\begin{array}{l}-7.7 \\
-4.1 \\
58.5\end{array}$ & $\begin{array}{r}148.5 \\
30.5 \\
348.0\end{array}$ & $\begin{array}{r}-4.4 \\
14.6 \\
69.0\end{array}$ & $\begin{array}{r}7 \\
37 \\
887\end{array}$ & $\begin{array}{r}22.0 \\
11.0 \\
1.9\end{array}$ \\
\hline $\begin{array}{l}\text { Eocene-- } \\
\text { PU 01*0 } \\
\text { PU 04* } \\
\text { PU 13* } \\
\text { PU 18 } \\
\text { PU 20 } \\
\text { PU 21 } \\
\text { PU 22* } \\
\text { PU 23 } \\
\text { PU } 24 \\
\text { PU } 25 \\
\text { PU } 26 \\
\text { PU } 27 \\
\text { PU } 28 \\
\text { PU } 30\end{array}$ & $\begin{array}{l}\text { ligo } \\
6 \\
5 \\
8 \\
4 \\
8 \\
4 \\
7 \\
10 \\
10 \\
7 \\
5 \\
4 \\
7 \\
8\end{array}$ & $\begin{array}{r}\text { ene } \\
1.8 \\
353.8 \\
5.6 \\
180.0 \\
349.0 \\
188.0 \\
1.5 \\
187.0 \\
339.8 \\
358.0 \\
177.0 \\
181.0 \\
176.0 \\
209.0\end{array}$ & $\begin{array}{r}16.0 \\
48.0 \\
41.0 \\
-43.0 \\
45.0 \\
-62.0 \\
55.1 \\
-55.0 \\
46.5 \\
56.5 \\
-40.6 \\
-45.0 \\
-46.8 \\
-42.8\end{array}$ & $\begin{array}{r}358.7 \\
25.0 \\
18.0 \\
209.0 \\
16.0 \\
226.0 \\
43.8 \\
234.0 \\
178.0 \\
44.0 \\
200.0 \\
208.0 \\
176.0 \\
204.0\end{array}$ & $\begin{array}{r}9.7 \\
42.8 \\
42.0 \\
-36.0 \\
53.0 \\
-60.0 \\
67.5 \\
-57.0 \\
-57.0 \\
54.6 \\
-48.0 \\
-48.0 \\
-46.8 \\
-51.3\end{array}$ & $\begin{array}{r}61 \\
144 \\
150 \\
30 \\
18 \\
125 \\
51 \\
207 \\
61 \\
107 \\
22 \\
61 \\
99 \\
27\end{array}$ & $\begin{array}{r}7.3 \\
5.2 \\
4 \\
12.8 \\
11.0 \\
6.2 \\
7.4 \\
3.0 \\
5.6 \\
5.1 \\
13.4 \\
9.0 \\
5.6 \\
9.5\end{array}$ \\
\hline
\end{tabular}

Mean before B.C.: $N=13 ; D=0.3 ; I=48.8 ; K=62 ; \alpha_{95}=5.3$ Mean after B.C. : $N=13 ; \mathrm{D}=25.7 ; \mathrm{I}=50.6 ; \mathrm{K}=41 ; \alpha_{95}=6.0$

$\begin{array}{llllllrl}\text { Miocene } & & & & & & & \\ \text { PU 07 } & 7 & 357.0 & 48.5 & 357.0 & 48.5 & 47 & 7.7 \\ \text { PU 08 } & 6 & 345.0 & 58.0 & 345.6 & 58.0 & 55 & 7.6 \\ \text { PU 32 } & 7 & 353.0 & \mathbf{6 2 . 3} & 353.0 & \mathbf{6 2 . 3} & \mathbf{5 9 1} & \mathbf{2 . 2}\end{array}$

Mean: $N=3 ; \quad D=352 ; \quad I=56.4 ; \quad K=108 ; \quad \alpha_{95}=12$

Plio-Quatemary

$\begin{array}{llrlrrrr}\text { PU 02 } & 10 & 8.7 & 64.0 & 8.7 & 64.0 & 59 & 5.7 \\ \text { PU 03 } & 10 & 6.4 & 62.8 & 6.4 & 62.8 & 73 & 5.2 \\ \text { PU 29 } & 10 & 354.0 & 61.5 & 41.0 & 62.5 & 115 & 4.0\end{array}$

Mean before B.C: $N=3 ; D=2.8 ; I=63.0 ; K=443 ; \alpha_{95}=6.0$ Mean after B.C.: $N=3 ; D=19 ; I=64.0 ; K=86 ; \alpha_{95}=13.4$

* : Sites with samples from both polarities with antipodal directions and reported as normal. ${ }^{\circ}$ : Site rejected by the statistical calculation of the final mean direction. $n$ : number of studied samples, N: number of sites. D, I: mean declination and inclination values calculated for each site using Fisher's statistic before and after bedding correction (B.C.), the precision parameters of which being $K$ and $\alpha_{95}$. No mean direction has been calculated for the Cretaceous because the directions are too scattered.

would affect the different horizons at different epochs, because it would create a large amount of higher coercivity minerals.

We thus think that the observed stable paleomagnetic directions are primary and that their N-S alignment is a coincidence of the bedding attitude so that the directions after bedding correction can be interpreted in term of tectonics.

On the other hand no trustworthy results were obtained from the Cretaceous samples, the NRM of which was so weak in 8 of the 12 sites that it could not be measured with the required accuracy after the very first step of demagnetization at $120^{\circ} \mathrm{C}$. Others were unstable at a slightly higher temperature and yielded poor demagnetization diagrams and very scattered results. Most of the sites of Miocene age were too weakly magnetized to be measured. Others of the same age, as well as the sites from Calcareniti del Salento, yielded on the contrary good quality demagnetization diagrams; however, as reported in Table 1, the directions for these sites, all of which have a horizontal bedding, are normal and are aligned with the present magnetic field. Thus, 


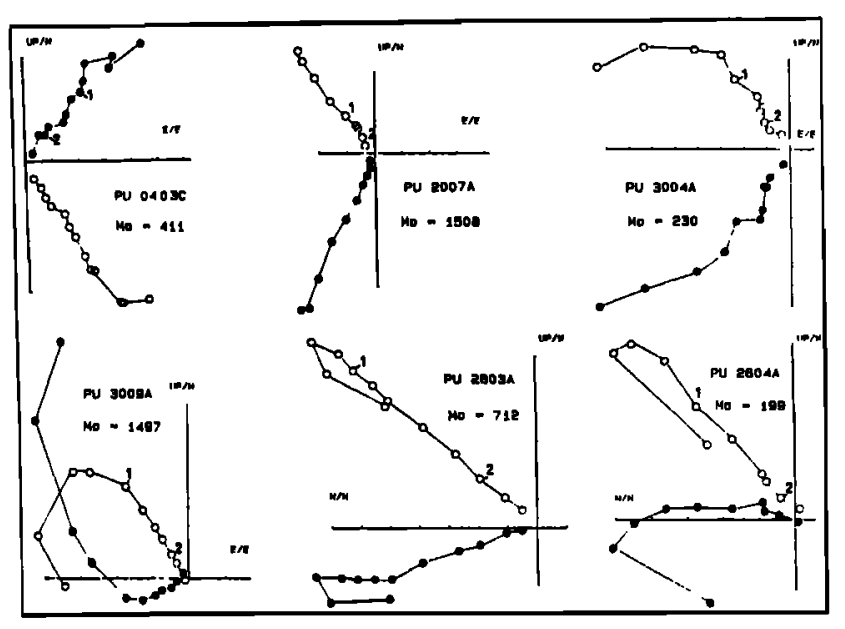

Fig.3. Typical demagnetization diagrams. Full circles: horizontal projection; open circles: vertical projection. The last step varies between $440^{\circ} \mathrm{C}$ and $520^{\circ} \mathrm{C}$, numbers 1 and 2 indicating the steps $240^{\circ} \mathrm{C}$ and $400^{\circ} \mathrm{C}$ respectively. The NRM intensity (Mo) is reported in $10^{-6} \mathrm{~A} / \mathrm{m}$ unit.

most probably these formations have been remagnetized in the present field.

Clearly, the very low NRMs of the great majority of the samples from the different sites and their instability upon demagnetization is the major difficulty in conducting paleomagnetic studies in this region.

\section{Discussion and conclusion}

The only reliable results are those obtained from the EoOligocene Calcari di Castro, the mean paleomagnetic direction of which is after bedding correction: $\mathrm{N}=13 ; \mathrm{D}=25.7^{\circ} ; \mathrm{I}=50.6^{\circ}$; $\mathrm{K}=41 ; \alpha_{95}=6.0^{\circ}$. Tertiary paleomagnetic data from the major stable plates are sparse, so that the published African and European APWP show large discrepancies [Van der Voo and French, 1974; Tauxe et al., 1983; Besse, 1986; Westphal et al., 1986]. However, whatever the APWP we use, the directions obtained from the Calcari di Castro indicate that Southemmost Apulia has undergone a clockwise rotation of $20^{\circ}$ to $25^{\circ}$ with respect to Africa and of $15^{\circ}$ to $20^{\circ}$ with respect to Europe since the Oligocene without any significant differential movement between Eocene and Oligocene.

One of the hypotheses could be that the observed rotation is a local one. Indeed, the "Calcari di Castro" are found only in extreme southeastem Apulia but deep drillings [Mostardini and Merlini, 1986] and paleogeographic reconstructions [D'Argenio et al., 1973] show that this transitional facies is in stratigraphical, sedimentological and structural continuity with the Mesozoic carbonatic platform [Martinis, 1962]. Moreover, this region is

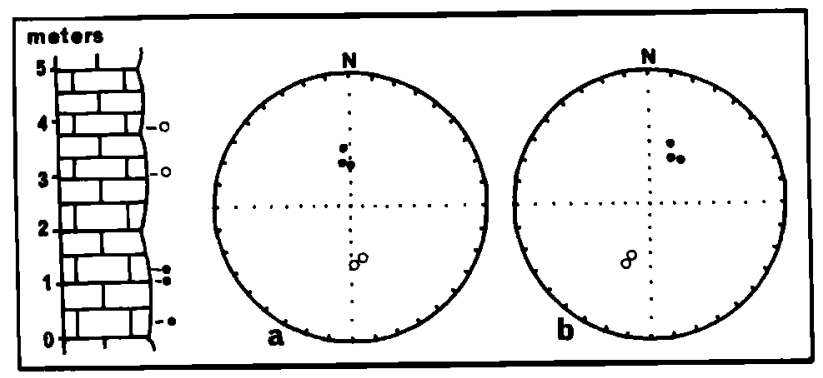

Fig. 4: One example of a site in which samples of both polarities are present at different stratigraphic levels as it is shown by the stratigraphic column. a, b: stereographic projection of the direction of the stable component for each sample from this site before and after bedding correction respectively. only slightly tectonised and a fault geometry which could explain a block rotation has not been observed. Although we are well aware that we need more paleomagnetic data in a larger area to confirm these preliminary results, it seems to us more realistic to think that this rotation has a regional significance.

This rotation is of opposite sense to the one documented from Cretaceous formations in the Gargano which is also part of the autochthonous carbonatic platform. This implies that either the rotation measured in the Cretaceous formations may have been "overprinted" by the more recent clockwise rotation or that a major discontinuity decoupled the Gargano from the Salento during the Late Tertiary time. We have no argument to rule out the first possibility. However the second one is consistent with various geological and geophysical analyses which have shown important differences between these two regions. For example, the depth of the Moho decreases from $35 \mathrm{~km}$ in the Murge-Salento to $25 \mathrm{~km}$ in the Gargano [Morelli and Nicolich, 1988 ] and positive Bouguer anomalies increase from $40-80 \mathrm{mgal}$ to $120 \mathrm{mgal}$ [Morelli, 1975]. Heat flow values, very low in Southern Apulia $\left(<40 \mathrm{~mW} / \mathrm{m}^{2}\right)$, are more than $60 \mathrm{~mW} / \mathrm{m}^{2}$ in Gargano [Della Vedova et al., 1988]. In addition, major historical earthquakes have occurred in the Gargano, while in the Murge-Salento no major earthquake has been recorded and the region is seismically quiet.

The stratigraphy and the structural pattem of the two regions also show some differences [Vezzani, 1975]: the Gargano is characterized by $\mathrm{E}-\mathrm{W}$ lineaments, in addition to the NW-SE ones that are predominant in the Murge-Salento. Moreover folds and compressive lineations are common in Gargano compared to the rest of Apulia [Ortolani and Pagliuca, 1988]. Between the two regions an important transcurrent (maybe transpressional) E-W fault zone, parallel to the main structural axis, passes through the lower part of the Gargano promontory (from S. Severo to Mattinata) and continues off-shore for some tens kilometers [Finetti and Del Ben, 1986; Ortolani and Pagliuca, 1988]. Southwards, in the Ofanto river valley, large extensional faults isolate the Gargano from the Southern Apulia.Thus Apulia and the Gargano regions may indeed rotate independently of each other, decoupled along these faults.

On the other hand, the sense of the rotation of the Salento is the same as in northwestern Greece, on the other side of the Southem Adriatic sea, where two phases of clockwise rotation of about $25^{\circ}$ each have been documented, one during the Middle Miocene and one during the Plio-Quaternary period [Laj et al., 1982; Kissel et al., 1985]. The rotation of the Salento represents about one half of the total rotation of Greece, and is about equal to either of the two separate rotational episodes. We suggest that the rotations in Greece and Salento are related, although paleomagnetic data alone do not provide conclusive argument for associating the rotation of the Salento directly with either one of the two phases documented in Greece. The age of the Salento rotation is unconstrained because no formation younger than the Oligocene gave reliable paleomagnetic results. It may, however, be more realistic to relate the rotation of the Salento to the most recent rotation of northwestern Greece, as independent geophysical observations suggest a present day geological continuity across the Southern Adriatic Sea. For instance, no major structural discontinuity has been observed in the Otranto Channel [Auroux et al., 1985; Finetti and Del Ben, 1986] and similarities of facies distribution between the two coasts of the Adriatic sea and a stratigraphic continuity at different epochs have been documented by several authors [De Giuli et al., 1987]. In addition, earthquakes with shallow $(14 \mathrm{~km})$ or deep $(100 \mathrm{~km})$ epicenters located in both the eastem and western parts of the southern Aegean area always show the same felt area boundaries in Southem Italy [Margottini, 1982].These boundaries probably correspond to the deep, older continental crust which appears to behave as a rigid unit from the Greek areas to Apulia. Thus we can notice the easy propagation of the seismic energy from one region to the other, as Mantovani et al. [1986] also suggested on the basis of different, more quantitative data.

The deep drillings performed into the foredeep areas and into the chain [Mostardini and Merlini, 1986] clearly show the presence of the Apulian carbonatic platform about $5,000 \mathrm{~m}$ under the Apennines, in areas as far as $50 \mathrm{~km}$ from the allochthonous 
front. The Apulian plate that is thrust under the Appenines may thus be in continuity with Northwestem Greece. This slab could also be responsible for the deep seismicity in the Southern Tyrrhenian Sea.

This hypothesis that Southern Apulia and Northwestern Greece are a single unit is in contradiction with many models for the geodynamical evolution of the central Mediterranean which assume a major structural discontinuity in the southem Adriatic Sea. The main reason for the postulated existence of this discontinuity, however, is that it has been implicitly assumed that the anticlockwise rotation of peninsular Italy, documented by the paleomagnetic studies of Cretaceous formations, can be extrapolated to the present and compared to the seismic, seismotectonic and neotectonic results. However the relationship between seismic and rotational paleomagnetic data have always to be treated cautiously. Seismicity represents present-day deformation whereas paleomagnetic data represent the integrated rotation over a considerable period of time, and the two may, in principle, differ markedly.

Most significantly, the new data indicate that southward of the studied area, there should exist or have existed a zone that decouples the Apulian platform from Africa during the period of rotation. Such a decoupling zone is also predicted along the Medina wrench by a different model [Jongsma et al., 1987].

The limited number of sites suitable for reliable paleomagnetic studies sampled in this preliminary study has not allowed us to address major problems which will have to be considered in future work, such problems for instance as the identification of geographical boundaries of the clockwise "rotating plate", the problem of its coupling with the Gargano in the North and its relations with the Ionian area in the South. Future paleomagnetic sampling will also be necessary to see whether the rotational movement ends west of the Appenine overthrust, or whether a rotation is also detected in the units along the Tyrrhenian Sea.

Acknowledgements. We wish to thank J. Labeyrie and $R$. Walcott for many fruitful suggestions and dicussions, and also G. P. Cavinato and L.Sagnotti who helped in the field work.

The financial support was given by the CEA, the CNRS and the CNR. This is the contribution 957 from the CFR.

\section{References}

Auroux, C., J. Mascle, R.Campredon, G.Mascle, and S. Rossi, Cadre géodynamique et évolution recente de la dorsale Apulienne et de ses bordures,Giorn. di Geol.,3-47,101-127, 1985.

Besse, J., Cinématique des plaques et dérive des pôles magnétiques: évolution de la Téthys, collisions continentales et couplage noyau-manteau.Thèse d'Etat, Université Paris VII,380p, 1986.

Besse, J., J. P. Pozzi, G. Mascle, and H. Feinberg, Paleomagnetic study of Sicily: consequences for the deformation of Italian and African margins over the last 100 million years, Earth Planet. Sci. Lett., 67, 377-390, 1984.

D'Argenio, B., T. Pescatore, and P. Scandone, Schema geologico dell'Appennino meridionale, Rend. Acc. Naz, Lincei, 183, 49-81, 1973.

De Giuli, C., F.Masini, and G.Valleri, Paleogeographic evolution of the Adriatic area since Oligocene to Pleistocene, Riv. It. Paleontol. Strat. 23, 1. 109-126, 1987.
Della Vedova, B., I. Marson, G. F. Panza, and P. Suhadolc, Upper mantle properties along a profile intersecting EGT (Corsica-Istria), XIII EGS Gen. Assembly, Bologna, 1988.

Finetti, I., and A. Del Ben, Geophysical study of the Tyrnhenian opening, Boll. Geof. Teor. Appl. 28. 110, 75-151, 1986.

Jongsma, D., J. M. Woodside, G. C. P. King, and J. E. van Hinte, The Medina Wrench: a key to the kinematics of the central and eastern Mediterranean over the past $5 \mathrm{Ma}$, Earth Planet. Sci. Lett., 82, 87-106, 1987.

Kissel, C., C. Laj and C. Muller, Tertiary geodynamical evolution of Northwestem Greece paleomagnetic results, Earth Plan.Sci.Lett. 72, 190-204, 1985 .

Laj, C., M. Jamet, D. Sorel, and J. P. Valente, First paleomagnetic results from Mio-Pliocene series of the Hellenic sedimentary arc. In: Geodynamics of the Hellenic Arc and Trench., Le Pichon X, S. S Augustuthis, and J. Mascle Eds. Tectonophysics, 86, 45-67, 1982.

Lowrie,W., A paleomagnetic overview of the Alpine system, Mem. B.R.G.M. 115, 316-330, 1980.

Lowrie, W., Paleomagnetism and the Adriatic Promontory: a reappraisal, Tectonics, 5, 5, 797-807, 1986 .

Mantovani, E., D. Albarello, and M. Mucciarelli, Seismic activity in North Aegean region as a middle term precursor of Calabrian earthquakes. Phys. Earth Planet. Inter., 44, 264-273, 1986.

Margottini, C., Osservazioni su alcuni grandi terremoti con epicentro in Oriente. Campo macrosismico in Italia del terremoto del 1903, CNEN-RT/AMB (82)3, 1982.

Martinis, B., Lineamenti strutturali della parte meridionale penisola salentina, Geol. Rom. 1, 11-23, 1962.

Morelli, C., Gravity map of Italy, Quad. Ric. Sci. CNR.90, 1975.

Morelli, C., and R. Nicolich, Activity on and the importance of Geophysical Research (1982-1987) along the EGT southern segment, XIII EGS Gen. Assembly, Bologna, 1988.

Mostardini, F. and S. Merlini, Appennino centro-meridionale, sezioni geologiche e proposta di modello strutturale, $73^{\circ}$ Congr. Soc.Geol.It. Roma, 1986.

Ortolani, F. and S. Pagliuca, Tettonica transpressiva al Gargano e rapporti con le catene appenninica e dinarica, Boll. Soc. Geol. It. in press, 1988.

Tauxe, L., J. Besse, and J. L. La Brecque, Paleolatitudes from Leg 73 sediment cores: implications for the apparent polar wander path for Africa during the late Mesozoic and Cenozoic, Geophys.J.R.Astron.Soc. 73, 315-324, 1983.

Vandenberg, J. and A. A. H. Wonders, Paleomagnetic evidence of large fault displacement around the Po-basin, Tectonophysics, 33, 301-320, 1976

Vandenberg, J. and J.D.A. Zijderveld, Paleomagnetism in the Mediterranean area, Alpine Med. Geodyn, Ser. 7, 83-112, 1982.

Van der Voo, R. and R. B. French, Apparent polar wandering for the Atlantic-bordering continents: Late Carboniferous to Eocene, Earth. Sci. Rev. 10, 99-119, 1974.

Vezzani, L., Lithostratigraphic complexes and evidence for tectonic phases in the Molise-Puglia-Lucania Apennines, In: Structural Model of Italy. Ouadr. Ric. Sci. CNR, 90, 1975.

Westphal, M., M. L. Bazhanov, J. P. Lauer, D. M. Pechersky and J. C. Sibuet, Paleomagnetic implications on the evolution of the Tethys belt from the Atlantic ocean to Pamir since Trias, Tectonophysics. 123, 37-82, 1986.

( Received: February 29, 1988 Accepted: May 10, 1988) 